\title{
The Effect of Amifostine on Pathophysiological Changes in Vasogenic Brain Edema Induced by an Experimental Cold Injury Model
}

\author{
Deneysel Soğuk Yaralanma Modeli ile Oluşturulan Vazojenik Beyin \\ Ödeminde Ortaya Çıkan Patofizyolojik Değişiklikler Üzerine \\ Amifostinin Etkisi
}

Kemal CENGIZ1 ${ }^{1}$ Ethem GOKSU ${ }^{1}$, Arzu CENGIZ ${ }^{2}$, Ozlem OZSOY ${ }^{3}$, Ruken TAN ${ }^{3}$, Necdet DEMIR Inanc GURER ${ }^{5}$, Saim KAZAN ${ }^{1}$

${ }^{1}$ Akdeniz University, School of Medicine, Department of Neurosurgery, Antalya, Turkey

${ }^{2}$ Akdeniz University, School of Medicine, Department of Nuclear Medicine, Antalya, Turkey

${ }^{3}$ Akdeniz University, School of Medicine, Department of Physiology, Antalya, Turkey

${ }^{4}$ Akdeniz University, School of Medicine, Department of Histology and Embryology, Antalya, Turkey

5 Akdeniz University, School of Medicine, Department of Pathology, Antalya, Turkey

Corresponding Author: Ethem GOKSU / E-mail: ethemgoksu@mynet.com

\begin{abstract}
AIM: To investigate the effects of amifostine, a cytoprotective agent, on pathophysiological changes in vasogenic brain edema induced by an experimental cold injury model and to compare these changes with dexamethasone.

MATERIAL and METHODS: A total of 138 rats divided into 6 groups. Brain water content (BWC), malondialdehyde (MDA) concentration and myeloperoxidase (MPO) activity in brain tissue were calculated to evaluate the pathophysiological changes following experimental cold injury. In addition, effects of cold injury on cell structure were assessed with direct light and transmission electron microscopy (TEM).

RESULTS: Extent of edema, MDA and MPO levels were significantly higher in cold injury groups than in controls. Although a decrease was noted in these parameters in both the amifostine and dexamethasone groups, the differences were significant only for MDA concentration in dexamethasone group, and for MPO activity in both groups. In addition, there was a significant difference between the group in which amifostine was administered prior to cold injury and dexamethasone group for MPO activity. Histopathologically, positive effects were observed in treatment groups.

CONCLUSION: Despite several positive effects of amifostine, its superiority to dexamethasone could not be clearly demonstrated. Further experimental and clinical studies are warranted to better delineate the neuroprotective effects of amifostine.
\end{abstract}

KEYWORDS: Amifostine, Cold injury, Rat, Vasogenic edema

öz

AMAÇ: Deneysel soğuk yaralanma modeli ile oluşturulan vazojenik beyin ödeminde ortaya çıkan fizyopatolojik değişiklikler üzerine sitoprotektif bir ajan olan amifostinin etkinliğinin araştııılması ve bu etkilerin deksametazonla karşılaştırılması amaçlandı.

YÖNTEM ve GEREÇLER: Çalışmada 6 grupta toplam 138 rat kullanıldı. Soğuk yaralanma modeli sonrası oluşan fizyopatolojik değişikliklerin değerlendirilmesinde; beyin su içeriği (BSi), beyin dokusunda malondialdehit (MDA) düzeyleri ve miyeloperoksidaz (MPO) aktivitesine bakıldı. Ayrıca direkt ışık ve transmisyon elektron mikroskopi (TEM) ile soğuk hasar uygulanan dokularda hücre yapısı incelendi.

BULGULAR: Soğuk hasar uygulanan grupta ödem genişliği, MDA düzeyi ve MPO aktivitesi kontrol gruplarına göre anlamlı oranda yüksek bulundu. Amifostin ve deksametazon verilen gruplarda, bu parametrelerde azalma saptanmakla birlikte sadece deksametazonla MDA' daki azalma ile her iki gruptaki MPO aktivitesindeki azalma istatistiksel olarak anlamlı bulundu. Ayrıca, MPO aktivitesi yönünden soğuk hasar öncesi amifostin uygulanan grupla, deksametazon grubu arasındaki fark anlamlı idi. Histopatolojik olarak tedavi gruplarında olumlu etkiler saptandı. SONUÇ: Amifostinle bir takım olumlu etkiler gözlenmekle birlikte, deksametazona bariz üstünlüğü gösterilememiştir. Amifostinin nöroprotektif etkilerinin başka deneysel ve klinik çalışmalarla desteklenmesi gerekmektedir.

ANAHTAR SÖZCÜKLER: Amifostin, Soğuk yaralanma, Sıçan, Vazojenik ödem 


\section{INTRODUCTION}

Cerebral edema is defined as the pathophysiological condition arising from an increase in water and sodium content of the brain. It is a common phenomenon in ischemic, infective, and tumoral pathologies and traumatic injuries of the brain and it may lead to disability and death due to severe focal or diffuse disorder through an increase in the intracranial pressure. Despite a variety of proposed mechanisms for its development, cerebral edema is primarily categorized into three groups as follows: vasogenic, cytotoxic, or interstitial (hydrocephalic) $(13,32,39)$.

The type of cerebral edema is partly determined by the underlying pathology, and yet no standard treatment has been developed. Steroids and hyperosmolar fluid administration are the most commonly utilized therapeutic options. In addition to such treatments, many interventions in clinical practice such as controlled respiration, rising the position of the head, cerebrospinal fluid drainage, moderate hypothermia, barbiturate treatment, and decompressive surgery aim at reducing the intracranial pressure and preventing the secondary injuries rather than halting the occurrence of the edema.

Free radical formation is one of the mechanisms implicated in the development of cerebral edema. Numerous experimental studies have been conducted to search for treatments that may decrease the effects of free radical groups, unfortunately with no clinically applicable results. Amifostine [s-2- (aminopropyl - amino) ethylphosphorothioic acid] is a free radical scavenger that has been used as a radioprotective and cytoprotective agent in cancer treatment. It is thought to exert its protective effects through the elimination of free radicals formed during radiotherapy that cause damage in the cell membrane and DNA structure, and also through the elimination of carbon ions formed by the effect of alkylating and platinum-based cytostatic agents $(7,24)$. In the literature, there is no clinical or experimental study investigating the effects of amifostine on cerebral edema. The aim of this study was to investigate the effects of amifostine on pathophysiological changes in vasogenic brain edema induced by experimental cold injury model and to compare these changes with dexamethasone.

\section{MATERIAL and METHODS}

This study was carried out at the Experimental Animals Research Unit, Neurophysiology Laboratory of the Department of Physiology, TEMGA Unit of the Department of Histology and Embryology, and the Laboratory of the Department of Pathology at Akdeniz University School of Medicine. This study protocol was approved by the local Ethics Committee of Animal Researches at Akdeniz University School of Medicine.

Cold-induced brain edema was formed in rats according to a method originally described by Tominaga and Ohnishi and subsequently modified by Klatzo $(26,43)$. The following assessments were performed in all groups;

1. Brain water content (BWC) was measured in order to evaluate the extent of edema.
2. Malondialdehyde (MDA) assay. MDA is a marker of lipid peroxidation resulting from a reaction that occurs between free radicals and membrane lipids.

3. Polymorphonuclear leukocyte (PMNL) infiltration was studied with direct light microscope as a marker of inflammation. Tissue myeloperoxidase (MPO) activity was also measured to estimate the extent of neutrophil infiltration.

4. Hematoxylin - Eosin (HE) - stained sections were studied under the light microscope for the effect of histological and cellular changes associated with cold injury and edema.

5. Also, the effects of cold injury on cell ultrastructure were studied with transmission electron microscopy (TEM).

\section{Definition of the Study Groups}

Group I, Control group (b): Right hemisphere of the brain was directly removed without craniectomy and induction of edema.

Group II, Craniectomy group (c): Right hemisphere of the brain was removed 24 hours after the craniectomy.

Group III, Craniectomy with Edema (ce): Right hemisphere of the brain was removed 24 hours after craniectomy and induction of edema.

Group IV, Amifostine plus Craniectomy with Edema (aa): Amifostine was administered 10 min before craniectomy and induction of edema. Right hemisphere of the brain was removed after 24 hours.

Group V, Craniectomy plus Edema with Amifostine (ap): Amifostine was administered 10 min after craniectomy and edema formation. Right hemisphere of the brain was removed after 24 hours.

\section{Group VI, Craniectomy plus Edema with Dexamethasone} (d): Immediately after craniectomy and edema induction, dexamethasone was administered. Right hemisphere of the brain was removed after 24 hours.

The study was designed to include 23 rats in each of the six groups yielding a total of 138 rats. Including 4 rats that died during the surgical procedure, a total of 142 wistar-albino female rats weighing between 220 and 270 grams were used. Standard laboratory water and food supplementation for the rats was provided throughout the study period. Body temperature of the animals was maintained at about $37^{\circ} \mathrm{C}$ using a heating blanket (Harvard Homeothermic Blanket Control Unit) and monitored by rectal thermometers. Heart rates were constantly monitored. Hemoglobin, blood glucose, $\mathrm{pH}$, and $\mathrm{O}_{2}$ saturation were recorded at the time of the procedure.

Relevant articles of the Declaration of Helsinki were complied with throughout the experiment. 


\section{Anesthesia and Drug Administration}

Before surgical procedures, rats were anesthetized using intramuscular $60 \mathrm{mg} / \mathrm{kg}$ ketamine (Ketalar', Eczacıbaşı, Istanbul) and $9 \mathrm{mg} / \mathrm{kg}$ xylazine (Rompun', Bayer-Turkey, Istanbul). The parietooccipital region of the rats were shaved and the skin was cleaned with povidone iodine solution (Isosol', Merkez Laboratories, Istanbul). Additional intraoperative doses of ketamine and xylazine were required in some rats. Postoperative analgesic administration was routinely carried out (Paracetamol: 100-300 mg/kg 4 hours $1-2 \mathrm{mg} / \mathrm{ml}$ added to drinking water).

Amifostine (WR-2721, Ethyol ${ }^{\circ}$ ) was administered intraperitoneally (ip) at a dose of $200 \mathrm{mg} / \mathrm{kg}, 10 \mathrm{~min}$. before and $10 \mathrm{~min}$. after the cold injury to aa and ap groups respectively. Dexamethasone sodium phosphate $0.2 \mathrm{mg} / \mathrm{kg}$ was administered to group $d$, ip. The drug doses and routes of administration chosen for the study were based on previous experimental studies.

\section{Induction of Cold Injury}

Cold injury was induced according according to the method described by Tominaga and Ohnishi (43). In summary, animals that received anesthesia were positioned on a flat surface with the face down, extremities were plastered on the surface and front incisor teeth pulled with rubber band. Following a parietooccipital median longitudinal skin incision, sagittal, right coronal and lambdoid sutures were exposed, and the periosteum of right parietal region was separated from midline and temporal muscles. The temporal muscle was retracted to the right.

Between coronal and lambdoid sutures, a craniectomy, $5 \times 5$ $\mathrm{mm}$ in size, was carried out to the right of midline, including the parietal adjacency of temporal bone through the use of a dental drill. At the time of procedure, the surgical area was flushed frequently with normal saline in order to protect the cerebral tissue from the effect of temperature. The dura and superior sagittal sinus were kept intact. Bonewax and surgicell were used for hemostasis when necessary. A metal probe of $4 \mathrm{~mm}$ in diameter, calibrated and cooled in $-80^{\circ} \mathrm{C}$ with dry ice, was placed on intact dura in the parietal region with its own weight $(10 \mathrm{~g})$ for one minute. Following the procedure, the skin incision was sutured with 3.0 silk. Animals were then given postoperative analgesics and transferred to postoperative room for decapitation in 24 hours.

\section{Tissue Sampling}

Following the examination, 20 rats in each group were sacrificed with high dose phenobarbital, craniectomy was performed and their brains were removed. Cerebellum and brain stem were separated and right hemisphere of the brain was removed.

1. In all groups, a total of six right hemispheres were placed on aluminum foil and wet weights were measured. Immediately after weighing, samples previously kept in incubator at $70^{\circ} \mathrm{C}$ for 36 hours were then re-weighed and dry weights were established. The data obtained were used to calculate the BWC according the following formula $(38,43)$ :

Brain water content $\%$ (BWC \%) = (wet weight - dry weight / wet weight) $\times 100$

2. Six cerebral tissue samples per group were rinsed with saline for MDA measurement (lipid peroxidation measurement), placed in plastic tubes, capped, and then kept at $-80^{\circ} \mathrm{C}$ for subsequent examination.

Lipid peroxidation is an important marker of the reaction between membrane phospholipids and free radicals. Specifically, the reaction between hydroxyl radicals and membrane phospholipids stimulates lipid peroxidation which is associated with increased MDA concentrations that can be quantitatively estimated using the thiobarbituric acid (TBA) reaction (15). Absorbability of the color of MDA formed with TBA quantifies the lipid peroxidation in nanomolars per gram. Determination of tissue Thiobarbituric Acid Reactive Substances (TBARS) on cerebral tissue was carried out according to method proposed by Wasowicz et al. (45). Determination of protein content in cerebral tissues was conducted with a kit based on the Bradford method (4).

3. MPO activity (neutrophil activation assessment) of six cerebral tissue samples was carried out by placing the samples in $5 \mathrm{ml}$ homogenization buffer. The homogenates were kept in $-80^{\circ} \mathrm{C}$ until the time of analysis. MPO is an enzyme referred to as the neutrophil infiltration index. It is abundant in neutrophils and is considered to be an indicator of neutrophil accumulation in inflamed tissues $(22,25)$.

4. Twenty-four hours after the induction of trauma, two rats randomly selected from each group were sacrificed with high dose phenobarbital and total craniectomy was carried out. After brains were eviscerated, cerebellum and brain stem were separated and the right hemisphere of the brain was removed. Two cerebral tissue samples were placed in $10 \%$ formaldehyde in a plastic container for histopathological assessments and transferred to pathology laboratory, where the tissues were embedded in paraffin blocks. After sectioning, they were stained with $\mathrm{HE}$ and then examined under light microscope.

5. Following direct anesthesia, three animals entered deep anesthesia first by intramuscular injection of ketamine $(60 \mathrm{mg} / \mathrm{kg})$, and cerebral perfusion-fixation was carried out with Somogyi-Takagi fixative solution containing $4 \%$ glutaraldehyde. Brains were then eviscerated with total craniectomy, right hemispheres were removed and placed in Somogyi-Takagi fixative free from glutaraldehyde for transmission electron microscopy (TEM) examination.

\section{Statistical Analysis}

Data obtained from the study groups were statistically compared using SPSS 10.0 statistical software package for 
Windows. Difference between the groups was analyzed with Kruskal-Wallis (non-parametric ANOVA) test. Pairwise comparisons were carried out using Mann-Whitney-U test. P values $<0.05$ was considered statistically significant.

\section{RESULTS}

For the study purposes, 6 groups of rats, 23 in each making a total of 138 , were used. The groups were similar in terms of physiological parameters (body temperature, pulse measurements, hemoglobin, $\mathrm{pH}$, glucose, $\mathrm{O}_{2}$ saturation, $\mathrm{pCO}_{2}$ values) ( $p>0.05)$.

\section{BWC Findings}

A total of 36 right hemispheres, with six samples from each group, were weighed wet and dry to calculate BWC. Although BWC was higher in group $b$ than in $c$, the difference was not statistically significant ( $p>0.05$ ). On the other hand, BWC was significantly higher in groups ce, aa, ap, and d as compared to groups $b$ and $c(p<0.05)$. There were no significant differences between groups ce and aa, ap, d. Also, the comparison of BWC between treatment groups (aa, ap and d) did not reveal any significant differences ( $p>0.05)$. However, despite similar BWCs, the greatest percent reduction occurred in group $d$, followed in decreasing order by groups aa and ap, respectively (Figure 1).

\section{MDA Results}

MDA (nmol/ mg protein) concentrations were calculated in six samples from each group making a total of 36 right hemisphere tissues. A statistically significant difference was not observed between groups $b$ and $c$ in terms of MDA measurements ( $p>0.05)$. As expected, MDA level was higher in ce group as compared to $c$ group $(p<0.05)$. There was a decrease tendency in MDA levels of aa and ap groups compared to c group, but it was not statistically significant
( $p>0.05)$. Also a statistically significant difference was not observed between aa and ap groups. However a significant decrease was detected in $\mathrm{d}$ group compared to ce group $(p<0.05)$ (Figure 2).

\section{MPO Results}

MPO activity (mU/mg protein), an indicator of neutrophil infiltration was calculated in six samples from each group, i.e. a total of 36 cerebral right hemisphere tissues. The difference in MPO activity between groups $b$ and ce was statistically significant $(p<0.05)$. There were no significant differences between group b and other groups ( $c$, aa, ap, d) ( $p>0.05)$. In pairwise comparisons between group $c$ and other groups, no statistically significant difference was found ( $p>0.05$ ).

The difference in MPO activity between ce and other groups (aa, ap, and $d)$ was significant $(p<0.05)$. Decrease in MPO activity in group aa did not bear any statistical difference from group ap ( $p>0.05)$, while there was a statistically significant decrease as compared to group $d(p<0.05)$. Difference in MPO activity between the groups ap and $d$ was not significant ( $p>0.05$ ) (Figure 3).

\section{Histopathological Assessment}

\section{Direct light microscopy}

As expected, normal histological findings were observed in the group that underwent direct brain sampling without craniectomy or cold injury (b), and in the group with craniectomy but without cold injury (c). In the group with craniectomy and cold injury where brain tissue sampling was performed after 24 hours without treatment (ce) findings associated with early ischemia such as congestion and perineural edema were observed under light microscopy. There was diffuse erythrocyte extravasation, with a few PMNL infiltration in some areas. There were no significant

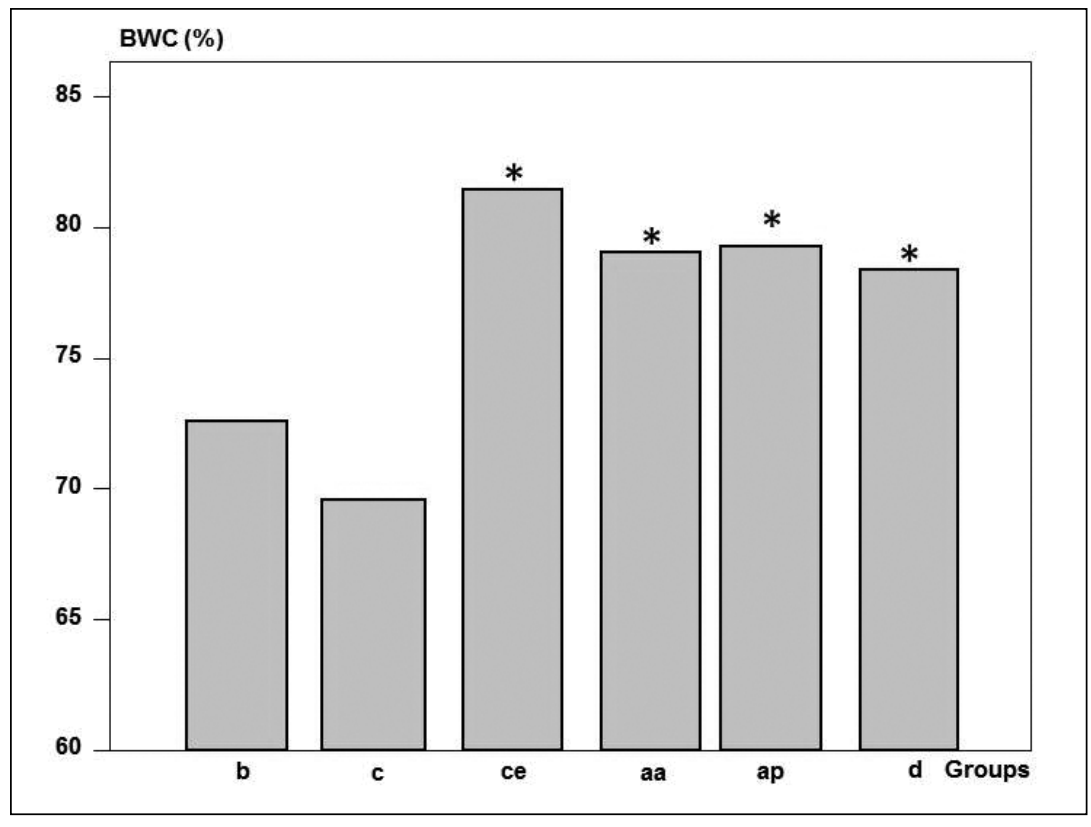

Figure 1: Brain water content (BWC) in study groups. *: $p<0.05$ vs. group b and $c$. 
differences in light microscopy results between the two groups (i.e. aa and ap) which underwent craniectomy and cold injury along with administration of amifostine before and after the injury. In these groups, congestion and perineural edema were still present, although they were of a lesser severity than in the group without treatment (ce). There were scarce areas of erythrocyte extravasation and neutrophil infiltration. There were less marked changes in the group that received dexamethasone after craniectomy and cold damage as compared to both amifostine groups (i.e. aa and ap). There was also less severe perineural congestion and edema. No erythrocyte extravasation and neutrophil infiltration were present.

\section{Ultrastructural Examination with TEM}

TEM showed normal ultrastructural findings at the cortical tissue samples from groups $b$ and c (Figure 4, 5). Dense edema was present in samples from group ce. Dilatation was observed in cortical capillaries due to severe edema in pericapillary astrocyte end-foot processes. Also dilatation in the neuropilic and neuronal cytoplasms, and particularly in GER cisterns was present. In contrast with the edematous swelling in astrocytes,
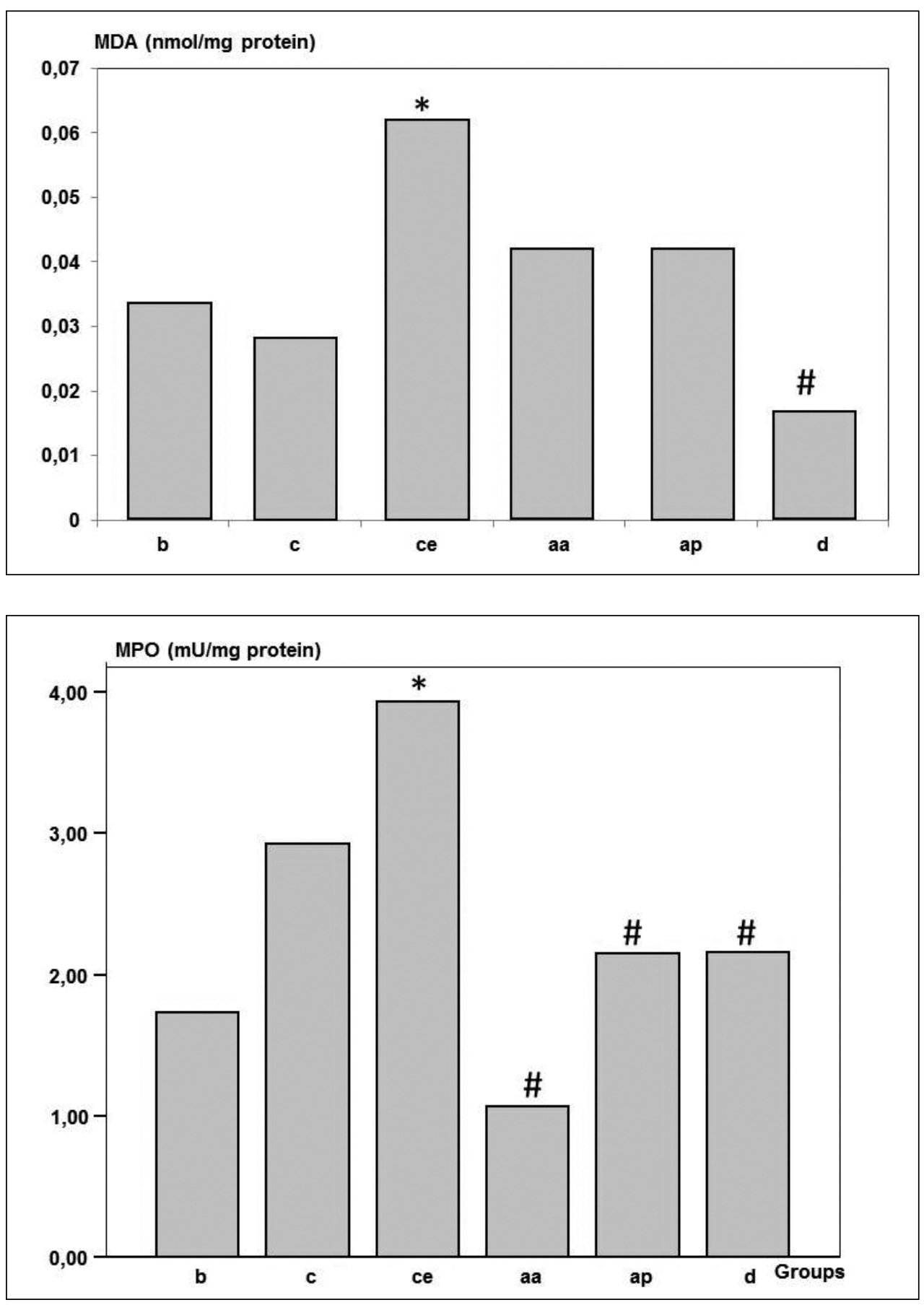

Figure 2: Cerebral tissue malondialdehyde (MDA) levels in study groups. *: $p<0.05$ vs. group c. \#: $p<0.05$ vs. group ce.
Figure 3: Cerebral tissue myeloperoxidase (MPO) activity levels in study groups. *: $p<0.05$ vs. group b. \#: $p<0.05$ vs. group ce. 
there was an electron-dense appearance in dendritic and axonal structures (Figure 6). TEM examination in groups aa and ap (i.e. amifostine treated groups) showed a significantly less marked ultrastructural injury occurring only at the level of dilatation of GER cisterns and neuronal cytoplasms. Mitochondrial and nuclear structures were normal (Figures $7,8)$. Although edema was significantly lower in the group that was given dexamethasone, there was an increase in the intensity of neuronal cytoplasms in addition to dilated GER cisternae (Figure 9).

\section{DISCUSSION}

Cerebral edema is classified into three groups, as cytotoxic, vasogenic, and interstitial (hydrocephalic) cerebral edema,

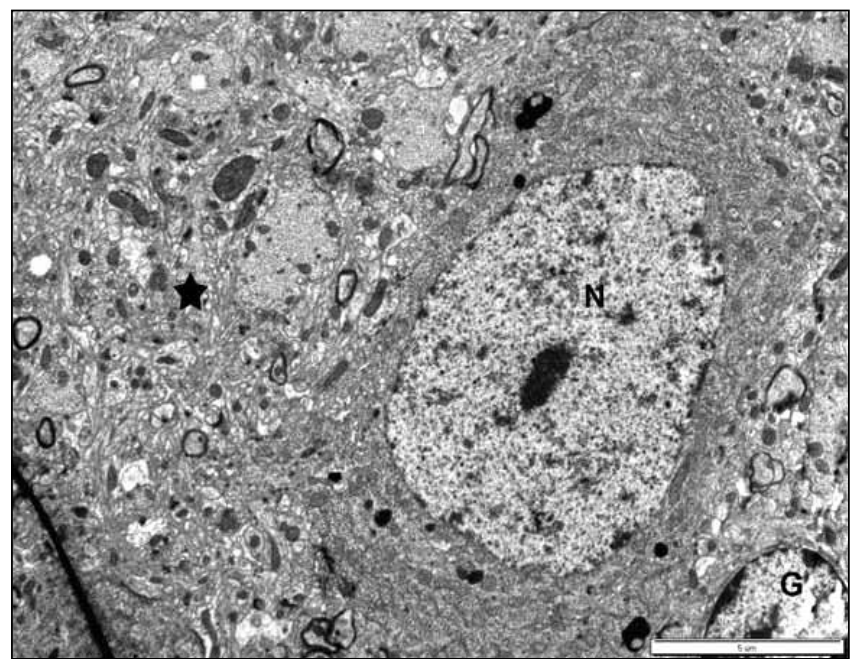

Figure 4: Normal cerebral cortical ultrastructure in the control group. Euchromatic neuron nucleus (N), glial cell (G) and neuropil (star) are observed.

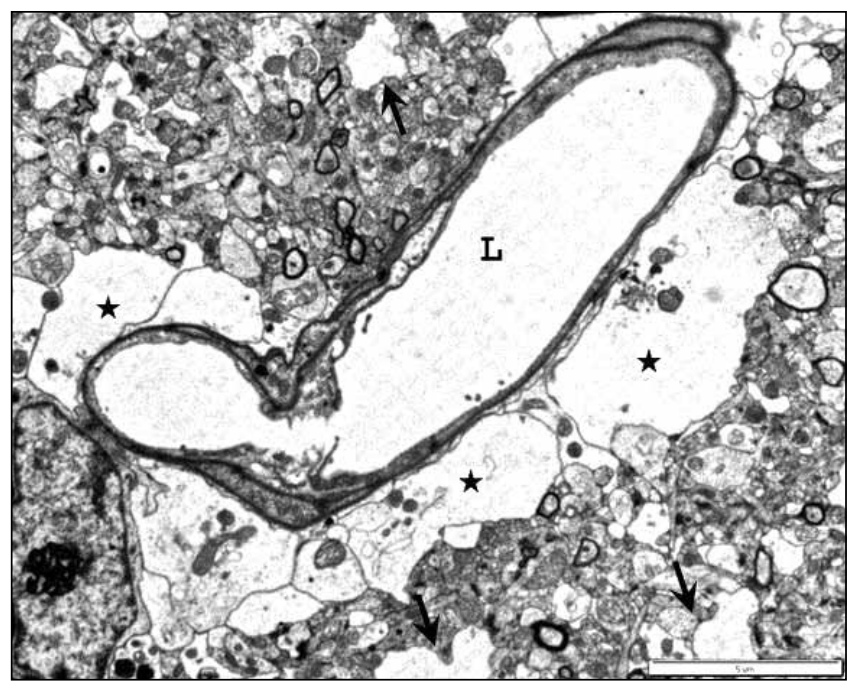

Figure 6: In the group that was subjected to cold injury, edema was observed in the pericapillary region. Severe edema is seen in astrocytic extensions (stars). Edematous extensions also continue into neuropil regions (arrows). L: lumen. depending on its pathogenesis $(13,32,39)$. Cytotoxic edema is due to a disrupted intracellular ion balance resulting from plasma membrane dysfunction and increased intracellular fluid content. On the other hand, vasogenic edema is thought to occur due to the increased permeability of blood-brain barrier (BBB) resulting from endothelial cell disruption. However, clinical observations suggest a multimodal mechanism for the occurrence of cerebral edema with subsequent local or generalized cerebral dysfunction $(3,9,15$, 32).

\section{Experimental Cerebral Edema Models}

Numerous experimental trauma models have been developed. Modern traumatic cerebral injury model was pioneered

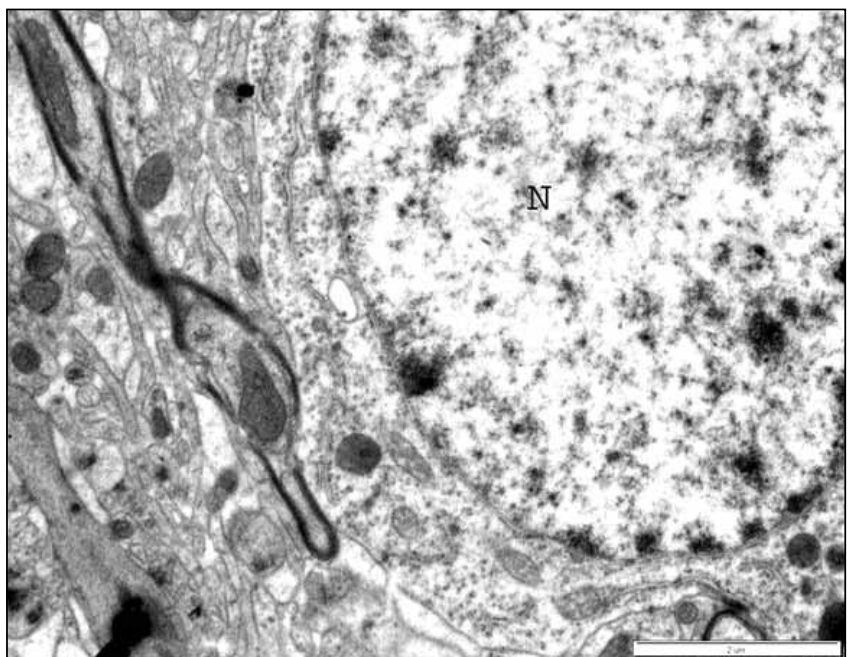

Figure 5: Craniectomy group; neuron ultrastructure exhibits normal appearance in the operative region. While nucleus $(\mathrm{N})$ preserves its euchromatic structure, membranous organelles of the membranes and cytoplasm have normal appearance.

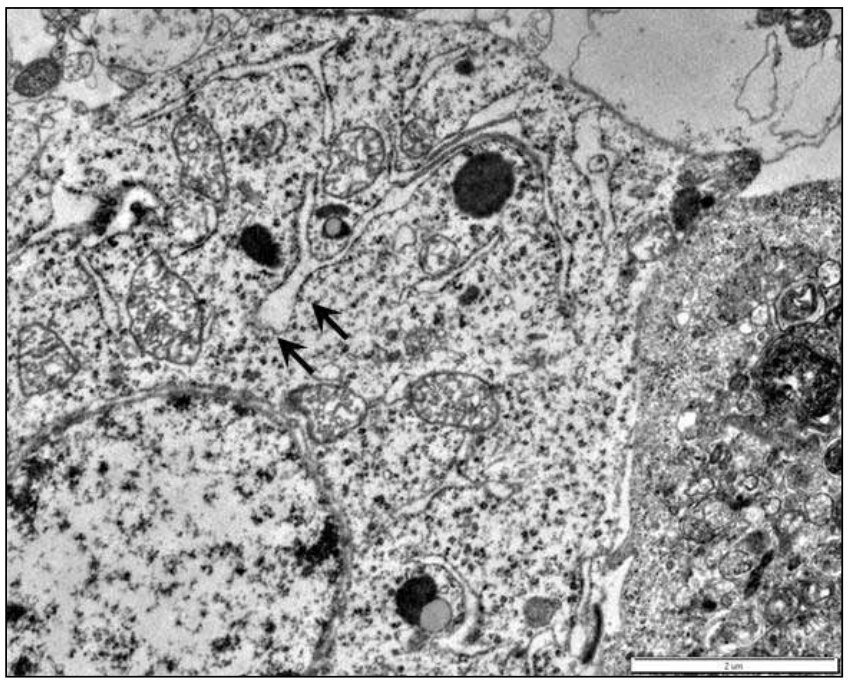

Figure 7: The ultrastructural damage in the group that received amifostine after injury involves only dilated GER cisterns in neuronal cytoplasms (arrows), with normal mitochondrial and nuclear structures. 


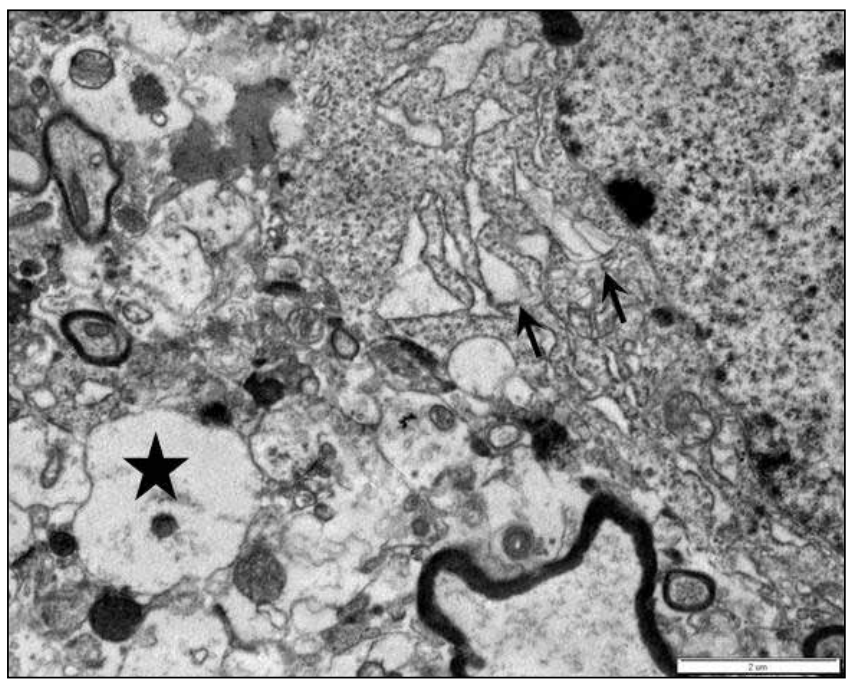

Figure 8: In the group that received amifostine after injury, GER dilatation (arrows) and edema in neuropil regions are observed (star).

in the early 1940s by Denny-Brown and Russell (10). Some examples subsequently developed include focal freeze injury and ischemic injury described by Klatzo (26), fluid percussion injury suggested by Lindgren and Linder (29), impact injury methods developed by Edward Hall (18) and Marmarou (14, 31 ), and acceleration trauma model by Ommoya and Gennarelli $(16,37)$.

Cold injury is one of the methods used for the induction of vasogenic cerebral edema and for studying the effects of secondary cerebral injury. Klatzo et al. were the first investigators to demonstrate the extravasation and migration of serum proteins from disrupted BBB through application of low temperatures to feline cortex in 1958 (26). This model underlines that edema occurs initially at a focal level, followed by the spread of the injury through leakage of the fluid out of the plasma membrane. Murakami et al. reported that edema due to cold injury triggered secondary damage and apoptotic cell death with excessive production of free $\mathrm{O}_{2}$ radicals, activated lipid peroxidation and neutrophils $(33,34,35)$.

We utilized the cold injury method in our study due to ease of use, and due to its ability to induce cerebral edema without severe parenchymal injury.

\section{Amifostine}

It has been known for many years that several antioxidant compounds such as sodium thiosulphate and diethyldithiocarbamate that contain a thiol moiety may protect normal tissues from undesired effects of radiation and certain chemotherapeutic agents $(6,11)$. Amifostine (WR-2721), an organic thiophosphate compound, is administered as a "radioprotectant" in patients receiving radiotherapy. It is believed that protective effect is elicited by the elimination of free radicals that cause damage cell membrane and DNA structure, and also by the elimination of carbon ions formed by alkylating and platinum-based cytostatic agents $(7,24)$.

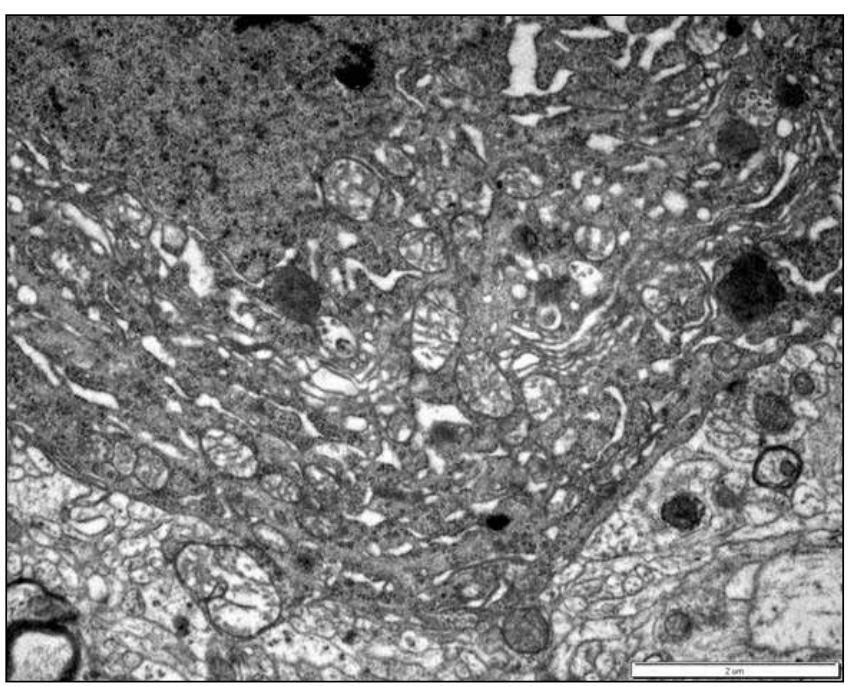

Figure 9: Significantly less severe edema is observed in the group that received dexamethasone, but there is an increased density of neuronal cytoplasms and dilated GER cisterns.

Although studies suggested protective effects against radiotherapy associated toxicity of the hematopoietic system, lungs, gastrointestinal system, and ears, clinical data on central nervous system radioprotection by amifostine are scarce. Although amifostine is unable to pass BBB, it may exert beneficial effects on the damaged $\operatorname{BBB}(7,24)$.

Spence et al. administered intrathecal amifostine to rats 45 min before single fraction radiotherapy of the central spinal cord and demonstrated a neuroprotective effect on the cervical spinal cord, particularly in the white matter and vascular elements. However, the same effect was not observed in peripheral extensions of the cervical spinal cord that are myelinated with Schwann cell (41). Guelman et al. investigated cerebellar morphological damage and motor disorder induced by single-fraction 5 Gy neonatal radiotherapy in rats. In that study, subcutaneous (sc) administration of 100 $\mathrm{mg} / \mathrm{kg}$ of amifostine $30 \mathrm{~min}$ before radiotherapy prevented such type of neurotoxicity (17). Alaoui et al. demonstrated that intraperitoneal amifostine $75 \mathrm{mg} / \mathrm{kg}$ administered 20 min after 2.5 Gy radiation on 15-day old rats did not provide any protection for the brain. A proposed possible explanation for the absence of an effect was the delayed administration (1). Lamproglou et al. applied whole brain radiation to 45day old rats. They concomitantly administered amifostine in varying doses. Statistically significant differences were observed in groups that were given 75 or $150 \mathrm{mg} / \mathrm{kg}$ doses of amifostine. In that study, the dose level of $37.5 \mathrm{mg} / \mathrm{kg}$ was less effective (28). In another study by Nieder et al., spinal cord protection was not provided by intrathecal amifostine. However, the authors noted that the difficulty of intrathecal application might have led to ineffectiveness. On the other hand, subcutaneous amifostine reduced the incidence of myelopathy (36).

\section{Brain Water Content (BWC)}

Disturbed BBB represents an essential pathological process for 
the development of cell damage, since it leads to brain edema and increased intracranial pressure, production of free oxygen radicals, and lipid peroxidation. Increase in the permeability of BBB is directly proportional to the severity of damage. It also has a particular role in the cell damage associated with vasogenic brain edema that occurs after the disruption of BBB. BWC increases following brain edema. Wet and dry weights of the samples are measured for BWC estimation. This may produce outcomes that are not completely accurate due to the presence of necrotic tissues $(13,32)$. Murakami et al. reported that increased BWC observed in the first few hours following cold injury model in rats may be an indication of the early movement of fluids into cerebral tissue from vascular compartment through disrupted BBB, as suggested by the results of BBB permeability studies (33-35). In another study of Erdinçler et al., BWC was found to be lower in young and old age groups compared to trauma groups (12).

In our study, BWC was significantly lower in the groups with the removal of cerebral tissue without craniectomy and cold injury and in the group with craniectomy without cold injury, as compared to the group with cold injury. When compared to the group that underwent craniectomy and edema with the treatment groups, a decrease was established in all groups in BWC but it was not found to be statistically significant. Antiedematous effect was slightly higher in the group that received dexamethasone compared to the amifostine group. This finding indicates that it would be possible to benefit from the antiedematous effect of amifostine in such conditions as diabetes mellitus, peptic ulcer, etc. in which the use of corticosteroids for antiedematous effect is limited.

\section{Free Radicals and Lipid Peroxidation in Traumatic Brain Injury}

It has been suggested that free oxygen radicals may have a role in functional disorder and cell death following ischemic and traumatic brain injury $(5,19)$. In such pathological conditions, free oxygen radicals cause brain edema through disruption of BBB due to endothelial cell damage or they directly affect the neuronal structure (23). The role of free oxygen radicals and lipid peroxidation in tissue damage in acute traumatic brain and spinal cord injury were previously established $(2,27)$. Biomembranes and intracellular organelles (mitochondria, endoplasmic reticulum) are sensitive to oxidative attacks due to presence of unsaturated fatty acids in membrane phospholipids. Free radicals are also toxic for proteins and they disrupt the enzymatic activity of the organism. Intracellular and extracellular ion balance is disrupted, intracellular calcium levels increase, and glycolytic and mitochondrial cellular energy pathways are impaired. TBA reaction represents a biochemical marker for the early lipid peroxidation in the acute period. MDA, a final product of lipid peroxidation, can easily be detected with this reaction (3). Increase in MDA formation, disruption in membrane cholesterol and inhibition of sodium-potassium adenosine triphosphatase ( $\mathrm{Na}-\mathrm{K}$ ATP'ase) pump activity are among the early effects of lipid peroxidation $(8,20)$. These undesirable effects of free radicals are compensated through the activity of certain enzymes and free radical scavengers including superoxide dismutase (SOD), catalase, glutathione peroxidase, glutathione reductase, glutathione transferase, vitamins $A, C$, and $E$. Their effects depend on variety of factors such as the rate of free radical formation, as well as free radical concentration and trace element intake (iron, copper, zinc, selenium, magnesium, etc.) $(4,22,44)$.

In our study, the difference in MDA levels (i.e. a final product of lipid peroxidation) in in control groups (b and $c$ ), cold injury group (ce), and treatment groups (aa, ap, and d) were compared. As expected, MDA levels were significantly higher in the cold injury group (ce). In dexamethasone group (d), a statistically significant decrease in MDA was observed. In amifostine groups (aa and ap), although a decrease in MDA levels compared to cold damage group was observed, the difference was not statistically significant.

\section{Histopathological Examination}

Inflammation is a common denominator in all types of tissue damage, and represents a process that enables the organism to eliminate the insulting factor by limiting its effects as to allow tissue repair. A major component of acute inflammation is the vascular response at the injury site. A short-lived vasoconstriction and then arteriolar vasodilation occur immediately after the injury. This causes both congestion, due to a greater amount of blood flowing into the capillary bed, and increased vascular permeability. Inflammatory cell infiltration begins with PMNL recruitment within the first few hours and reaches a peak on the first day of the trauma. Light and electron microscopy studies showed very small numbers of PMNL outside the blood vessels before the $4^{\text {th }}$ hour, after which an increase in the number occurs together with infiltration into tissues from the vessel wall. Preparations obtained at hour 8 show PMNL aggregations in the gray matter, and PMNL's appear as inclusion bodies within the white matter. Tissue preparations at 24-hour demonstrated degenerated neurons surrounded by PMNL's and cellular residues among PMNL's. PMNL's disappear within three days, during which they release their granular contents to the surroundings worsening the vascular, neuronal and glial damage with the effect of lytic enzymes. Inflammatory mediators such as histamine, plasma proteases, bradykinin, prostaglandins, leukotrienes, platelet-activating factor, free oxygen radicals, and serotonin accumulate at the injury site. These substances cause rapid progression of tissue damage. PMNL's that disappear from the environment are replaced with macrophages derived from microglial cells and circulation $(40,42)$.

MPO is an enzyme that is referred to as the neutrophil infiltration index, since it is a marker for the neutrophil accumulation at the inflamed tissues. Phagocytes release their granules containing myeloperoxidase into phagocytic vacuole in the extracellular space under the effect of different stimuli. In the presence of hydrogen peroxide $\left(\mathrm{H}_{2} \mathrm{O}_{2}\right)$, MPO produces certain powerful oxidative compounds, affecting 
the microorganism through reaction with biologically significant molecules $(21,25,30)$.

In our study, in the cold injury group (ce), highest level of MPO activity was determined. Early ischemic findings such as congestion, perineural edema, erythrocyte extravasation and PMNL infiltration were observed in the light microscopic examination as well, although they were not very prominent. MPO activity was significantly lower in treatment groups (aa, ap, d) compared to ce group. MPO activity in amifostine (aa and ap) and dexamethasone (d) groups suggested less severe early ischemic findings, with a significant difference between groups aa and d.

\section{Ultrastructural Examination with TEM}

Dilatation in pericapillary astrocytic end-foot processes due to severe edema was seen, particularly in the cortical capillaries. Also, dilatation was present in GER cisterns in edematous neuropils and neuronal cytoplasms (Figure 6). Contrary to edematous swelling observed in astrocytes, dendritic and axonal structures were found to produce more electrondense images in neuropils. More severe injury was observed in areas closer to the surface where trauma was applied and erythrocyte extravasation and cellular death were found in some neuropil regions. In deeper layers, deformation and a propensity to decrease in the severity of edema were observed together with increasing depth. Amifostine and dexamethasone did not result in complete recovery, despite reduction in the severity of the injury.

In conclusion, amifostine ameliorated cerebral edema and tissue damage induced by cold injury but its superiority to dexamethasone could not be clearly demonstrated. Neuroprotective effects of amifostine need to be supported by further experimental and clinical studies.

\section{REFERENCES}

1. Alaoui F, Pratt J, Trocherie S, Court L, Stutzmann JM: Acute effects of irradiation on the rat brain: Protection by glutamate blockade. Eur J Pharmacol 276:55-60, 1995

2. Barut S, Canpolat A, Bilge T, Aydın Y, Cokneşeli B, Kaya U: Lipid peroxidation in expermental spinal cord injury, time-level relationship. Neurosur Rev 1:53-59, 1993

3. Betz AL, Coester HM: Effect of steroids on edema and sodium uptake of the brain during focal ischemia in rats. Stroke 21(8):1199- 1204, 1990

4. Bradford MM: A rapid and sensitive method for the quantitation of microgram quantities of protein utilizing the principle of protein-dye binding. Anal Biochem 72:248-254, 1976

5. Braughler JM, Hall ED: Central nervous system trauma and stroke. Biochemical considerations of oxygen radical formation and lipid peroxidation. Free Radical Biol Med 6:289-301, 1989

6. Capizzi RL, Schein PS: Chemo and radition protection with amifostine. Advances in Biosciences 94:91-101, 1998
7. Capizzi RL: Clinical status and optimal use of amifostine. Oncology 13:47-59, 1999

8. Clendon NR, Allen H, Gordon WA, Bingham WGJ: Inhibition of $\mathrm{Na}-\mathrm{K}$ activated ATP'ase activity following experimental spinal cord trauma. J Neurosurg 49:563-568, 1978

9. Criscuola GR: The genesis of peritumoral vasogenic brain edema and tumor cysts: A hypothetical role for tumor-derived vascular permeability factor. Yale J Biol Med 66(4):277- 314, 1993

10. Denny-Brown D, Rusel WR: Experimental cerebral concussion. Brain 64:93, 1945

11. Dihne $M$, Block F, Korr $H$, Topper R. Time course of glial proliferation and glial apoptosis following excitotoxic CNS injury. Brain Res 902:178-189, 2001

12. Erdincler P, Tuzgen S, Erdincler UD, Oguz E, Korpinar A, Ciplak N, Kuday C: Influence of aging on blood-brain barrier permeability and free radical formation following experimental brain cold injury. Acta Neurochir (Wien) 144(2):195-199, 2002

13. Fishman RA: Brain edema. N Engl J Med 293:706-711, 1975

14. Foda MA, Marmarou A: A new model of diffuse brain injury in rats. Part II: Morphological characterization. J Neurosurg 80(2):301-313, 1994

15. Freeman BA, Crapo JB: Biology of disease: Free radicals and tissue injury. Lab Invest 47:412-426, 1982

16. Gennarelli TA, Adams JH, Graham DI: Acceleration induced head injury in the monkey I. The model, its mechanical and physiological correlates. Acta Neuropathol Suppl (Berl) 7: 23-25, 1981

17. Guelman LR, Zorrilla Zubilete MA, Rios H, Zieher LM: WR2721 (amifostine, ethyol) prevents motor and morphological changes induced by neonatal X-irradiation. Neurochem Int 42:385-391, 2003

18. Hall ED: High-dose glucocorticoid treatment improves neurological recovery in head-injured mice. J Neurosurg 62(6):882-887, 1985

19. Hall ED: Lipid antioxidants in acute central nervous system injury. Annals of Emergency Med 22:1022-1027, 1993

20. Hall ED: Inhibition of lipid peroxidation in central nervous system trauma and ischemia. J Neurol Sci 134:79-83, 1995

21. Halliwell B: Free radicals, reactive oxygen species and human disease: A critical evaluation with special references to atherosclerosis. Br J Exp Path 70:735-757, 1989

22. Halliwell B, Gutteridge JMC, Cross CE: Free radicals, antioxidants and human diseases: Where are we now? J Lab Clin Med 119:598-620, 1992

23. Ikeda $\mathrm{Y}$, Anderson JH, Long DM: Oxygen free radicals in the genesis of traumatic and peritumoral brain edema. Neurosurgery 25:679-685, 1989

24. Kalaycioğlu $M$, Bukowski R: Clinical status of the new cytoprotective agents, amifostine. Oncology 8:15-23, 1994

25. Kettle AJ, Winterbourn CC: Myeloperoxidase: A key regulator of neutrophil oxidant production. Redox Report 3: 3-15, 1997 
26. Klatzo I: Pathophysiology of brain edema: Pathological Aspects. In: Schürmann K, Brock M, Reulen HJ, Voth D (eds). Advances in Neurosurgery 1, Brain Edema, Pathophysiology and Therapy. Berlin: Springer Verlag, 1973:1-4

27. Kontos HA, Povilshock JT: Oxygen radicals in brain injury. CNS Trauma 3:257-263, 1986

28. Lamproglou I, Djazouli K, Boisserie G, Patin PH, Mazeron JJ, Baillet F. Radiation-induced cognitive dysfunction: The protective effect of ethyol in young rats. Int J Radiat Oncol Biol Phys 57:1109-1115, 2003

29. Lindgren S, Rinder L: Experimental studies in head injury. II. Pressure propagation in "percussion concussion". Biophysik 3(2):174-180, 1966

30. MacNaughton WK, Leach KE, Prud'homme-Lalonde L, Harding RK: Exposure to ionizing radiation increases responsiveness to neural secretory stimuli in the ferret jejunum in vitro. Int J Radiat Biol 72(2):219-226, 1997

31. Marmarou A, Foda MA, van den Brink W, Campbell J, Kita H, Demetriadou K: A new model of diffuse brain injury in rats. Part I: Pathophysiology and biomechanics. J Neurosurg 80(2):291-300, 1994

32. Marmarou A: The pathophysiology of brain edema and elevated intracranial pressure. Clevel Clin J Med 71:S6-S8, 2004

33. Murakami K, KondoT, Chan $\mathrm{PH}$ : Blood-brain barrier disruption, edema formation, and apoptotic neuronal death following cold injury. Acta Neurochir Suppl (Wien) 70:234-236, 1997

34. Murakami K, Kondo T, Sato S, Li Y, Chan PH: Occurrence of DNA fragmentation following cold injury induced brain edema. Neuroscience 87:231-237, 1997

35. Murakami K, Kondo T, Yang G, Chen SF, Morita-Fujimura Y, Chan PH: Cold injury in mice: A model to study mechanisms of brain edema and neuronal apoptosis. Prog Neurobiol 57:289-299, 1999

36. Nieder C, Andratschke $\mathrm{NH}$, Wiedenmann $\mathrm{N}$, Molls $\mathrm{M}$ : Prevention of radiation-induced central nervous system toxicity: A role for amifostine? Anticancer Research 24:38033810, 2004
37. Ommaya AK, Gennarelli TA: Cerebral concussion and traumatic unconsciousness. Correlation of experimental and clinical observations of blunt head injuries. Brain 97(4):633654,1974

38. Pappius HM: Cerebral edema and the blood-brain barrier. In: Neuwelt EA (ed), Implication of the Blood Brain Barrier and its Manipulation. Vol: 1, Basic Science Aspects. New York: Plenum Medical Book Company, 1989:293-309

39. Pollay M: Blood-Brain Barrier; Cerebral Edema. In: Wilkins RH, Rengachary SS (eds), Neurosurgery, Vol: 1. 2nd ed. Newyork: McGraw-Hill, 1996:335-344

40. Schwab ME, Bratoldi D: Degeneration and regeneration of axons in the lesioned spinal cord. Physiol Rev 76:319-370, 1996

41. Spence AM, Krohn KA, Edmondson SW, Steele JE, Rasey JS: Radioprotection in rat spinal cord with WR-2721 following cerebral lateral intraventricular injection. Int Radiat Oncol Biol Phys 12:1479-1482, 1986

42. Taoka Y, Okajima K: Spinal cord injury in the rat. Prog Neurobiol 56:341-358, 1998

43. Tominaga T, Ohnishi ST: Ion movements and edema formation in CNS injury. In: Ohnishi ST, Ohnishi T (eds), Central Nervous System Trauma and Research Techniques. Boca Raton. New York: CRC Press, 1995:85-94

44. Wada K, Alonso OF, Busto R, Clemens JA, Ginsberg MD, Dietrich WD: Early treatment with a novel inhibitör of lipid peroxidation (LY341122) improves histopathological outcome after moderate fluid percussion brain injury in rats. Neurosurgery 45(3):601-608, 1999

45. Wasowicz W, Jean N, Peratz A: Optimized steps in fluorometric determination of thiobarbituric acid-reactive substances in serum. Importance of extraction $\mathrm{pH}$ and influence of sample, preservation and storage. Clin Chem 39(12):2522-2526, 1993 